${ }^{13}$ Similar to the romanticized notion of cultural uniqueness, this class consciousness can also be considered an "imagined" component of the Irish national self (Anderson 1983). Indeed, while many nationalists of the time touted the need for collective economic control to aid the lower classes, they were simultaneously wary of alienating themselves from Irish landowners, whose support they saw as a necessary component to repealing the British Union (Nowlan 1994). Thus, while socialism contributed an anti-liberal and class unifying sense of self to Irish nationalist rhetoric, landlord privilege was implicitly understood as necessary to practical politics of the day.

\section{Border States and Civil Rights ACTIVISM Prior to 1955}

Jean Van Delinder

Oklaboma State University

Abstract

\begin{abstract}
Early civil rights activism prior to 1954 Brown case is marked by the absence of an intervening agency or organization associated with the type of mass mobilization found in the Montgomery Bus Boycott and other events in the later civil rights movement. The community action in Topeka, Kansas before Brown illustrates that civil rights actions have always been around, but only recent scholarship of the civil rights movement has brought these seemingly less significant campaigns to the foreground. The activism in Topeka, Kansas, characterized as indirect action tactics, was organized around primarily lo. cal level issues. These local level issues were also bistorically situated prior to the national push to desegregation which occurred after the 1954 Brown decision.
\end{abstract}

\section{Introduction}

The 1954 landmark Brown v. Board of Education of Topeka decision was a significant national step in the fight against segregation (Bloom 1987; Blumberg 1984; Branch 1988; Brenner 1994; Chafe 1980; Dalifume 1968; Greenberg 1994; Klarman 1994; Kluger 1976; Lawson 1991). It was also followed by and grew out of a significant local victory against segregation in the city of Topeka, Kansas. This paper discusses indirect action tactics un-

"Research funding was assisted by a Summer 1997 Faculty A\&S Grant, College of Arts and Sciences, Oklahoma State University. The author would like to thank Jack Weller for his helpful suggestions for this article. 
dertaken by African Americans in the city of Topeka between 1940 and 1954. During this period, multiple efforts were made to end segregation in public accommodations and schools. Though the name of the famous school desegregation case bears the title Brown v. Board of Education of Topeka, the role that the community of Topeka played in the events that led up to the court case under emphasized. This lack of interest might be related to the fact that Topeka, Kansas, was not located in the deep South, and did not have the same history of violence in race relations as, for instance, a place like Birmingham, Alabama. There were no spectacular events such as bombings, race riots, mass marches, or boycotts that characterized the mass mobilizations in the South. Little acknowledgment has been given to the fact that Topeka has its own unique history of race relations and that its subsequent type of resistance to segregation is related to those historical relations.

Indirect action tactics undertaken in Topeka prior to 1950 were affected by the curious mix of segregation and integration in public accommodations and public schools. The types of tactics described in this paper do not match up with previous sociological models of the Southern mass mobilization civil rights campaigns presented by Doug McAdam (1982) and Aldon Morris (1984). McAdam's model emphasized the growing national political insurgency of African Americans after 1938, and Morris' local movement center model emphasized actions conducted through African American churches and their clergy. Neither model provided an entirely adequate method by which to describe early civil rights activism in Topeka, Kansas prior to 1954. The indirect action tactics in Topeka were initiated to address local level grievances and did not have a national orientation until the Brown case oral arguments were first heard before the Supreme Court in December of 1952 (Wilson 1995: 127-155).

\section{Indirect Action Tactics in Topeka}

I argue that indirect action tactics were utilized to end segregation in Topeka where confrontational direct action tactics would have not been effective. Direct action perspectives emphasizing organizations and formal leadership developed to explain massmobilizations include Morris 1984; McAdam 1982; Killian and Smith 1960; Oberschall 1989; Killian 1984.

Indirect action tactics involve intermediate stages, not directly aimed at specific goals and involve social changes not immediately resulting from an action or cause. Indirect action tactics do not take the shortest course to the desired objective, or go straight to the point. The indirect action tactics used in Topeka included numerous actions that on first scrutiny appear to be unrelated. This is due to fact that the some of indirect action tactics were peaceful negotiations urging inclusion of African Americans in all public facilities: movie theaters, swimming pools, and schools.

\section{Historical Legacy of Kansas Race Relations}

The indirect action tactics used to help eliminate segregation were shaped by Kansas' mixture of segregationist and integrationist cultural patterns. The state's permissive segregation statute prohibited public funded school segregation except for elementary schools in its "first class" cities with a population over 15,000 (Wilson 1995:39). The expansion of Topeka's city limits through annexation the first part of the twentieth century, resulted in some African Americans being moved from integrated rural county schools to segregated city grade schools. This shift in the boundaries of the city also shifted color line practices in the newly annexed areas.

The resulting challenges to the color line were brought by those African Americans who were caught between pressure to preserve segregation within Topeka's city limits and the informal 
tradition of integration to which they were accustomed outside of the city limits. The period between 1940 following the Grabam case desegregating the junior high schools, and the 1954 Brown decision, can be characterized as a curious mix of accommodation and exclusion within the community of Topeka.

The indirect action tactics between 1940 and the 1954 Brown case can be divided into three phases, the first two of which are discussed in this essay. First, up to 1947 African Americans challenged Topeka's segregated public facilities-the municipal swimming pool and movie theaters. Local initiatives were shifted towards challenging elementary school segregation in a second phase beginning in 1948. These indirect action tactics were undertaken by breakaway groups from the local NAACP approaching the Board of Education and culminating in legal petition through the courts. Finally, in 1950, the third phase began when the legal case was carried forward by the lawyers of the national NAACP Legal Defense Fund in 1950. The legal basis and significance of the case changed in this phase from addressing local grievances to national public interests as it was incorporated into the NAACP Legal Defense Fund's desegregation agenda.

\section{Phase One: Challenges to Segregated Public Accommodations}

Indirect action tactics in this first phase were passed between groups and individuals, without any one organization or leader carrying the action forward. Though under the auspices of the NAACP, the participants who were involved were linked to individuals who sought to redress singular grievances.

During the 1940s, the mixture of segregation and integration practices in Topeka was a patchwork:

there was one colored hotel, the Dunbar, and all the rest were for whites. Almost no restaurants downtown served colored customers. Before the Second World War, a num- ber of...[restaurants] had a sign in the window reading: 'Negroes and Mexicans served in sacks only,' meaning they could take out food in bags but not eat on the premises. One movie theater in town admitted colored people to its balcony. Another, called the Apex, was for colored only. The other five movie houses were for whites only. The swimming pool at Gage Park was off-limits to colored, except one day a year when they were allowed in for a gala picnic (Kluger 1976:).

Limited access to public accommodations in Topeka was an ongoing issue for African Americans (Cox 1982:82-110; Wilson 1995:229). One such challenge to public accommodations in Topeka occurred in 1944. The local NAACP protested the proposed repeal of a municipal licensure requirement that "prohibited state universities, colleges, public schools, inns, hotels, or vehicles of public transportation" from discriminating on the "basis of race, color, or previous condition of servitude." 1 In the words of the president of Topeka's local chapter of the NAACP, R.J. Reynolds, stated that by repealing this law:

Topeka will be showing the rest of the cities in Kansas how to find a loophole in the law to deny Negroes of their rights.

Reynolds' public statement alone held open the permissive statute for three more years, illustrating an ambivalence toward segregation. However, in October 1947, things would change after an African American sued a local movie theater after he was denied admission because of his race. Because the theater managers were found guilty of violating the local municipal ordinance prohibiting discrimination on the basis of race, color, or previous condition of servitude. They were both fined $\$ 10.00 .2$ Though the matter was quickly resolved in favor of integration, the Topeka City Commission responded by repealing its permissive licensing requirement for local theaters a few weeks later, on October $1,1947.3$

Three days later on October 4, 1947, when Ava and Arthur Lee Stovall tried to enter the same Dickinson Theater that Phillip 
Burton had sued a month earlier, the Stovalls were not allowed to buy a ticket. ${ }^{4}$ The NAACP once again responded with a published statement of protest as it had in 1944. However, this time the civil rights provision preventing racial discrimination in public accommodations in Topeka remained repealed thus effectively removing the legal grounds to sue local businesses. 5 Movie theaters, as well as any other public facility in Topeka operating under a municipal license were no longer prevented from practicing segregation if they so wished.

Why Topeka revoked its permissive municipal ordinance at this time cannot be fully explained as simply a reaction to the indirect actions of the NAACP and other individuals involved in civil rights litigation. First, the NAACP was not the only organization involved in challenging segregation. Another bi-racial organization seeking to redress race issues was the local American Veterans Committee (AVC). The AVC was founded in 1946 by returning World War II veterans as an alternative to the American Legion, which was segregated (Kluger 1975:391). Its efforts challenging segregation coincided with those of the local NAACP. Though the AVC also targeted segregated institutions, its indirect actions were limited to peaceful public demonstrations. 6

The NAACP began another phase of indirect action after they protested that the repeal of the local civil rights ordinance allowed local businesses to institute racial discrimination. 7 The result of this setback caused the NAACP to shift attention from public accommodations to public schools. This would initiate another phase of indirect action tactics in 1948.

\section{Phase Two: A Local Challenge to Elementary School Segregation in Topeka}

Planning the challenge to Topeka's segregated schools was done by the local NAACP. The indirect action tactic it used first was to appear before the local school board and request that it compose a plan for integration. The NAACP formed an ad hoc "Citizens Committee" to undertake this task. This committee was a way to distance themselves from the local NAACP. 8

Previous involvement of the NAACP in school desegregation had been the Grabam case, a successful lawsuit against segregated junior high schools in 1940 which nevertheless divided its membership. On one side were the teachers and administrators who sought to protect their jobs and hostile white community leaders who sought to preserve the racial status quo. On the other side were those in the community - black and white - who were sympathetic to desegregation and the injustice it sought to redress. It was this faction, oriented toward civil rights and desegregation, which had gained control of the local NAACP in 1940 and remained in power throughout the desegregation era.

After the Grabam case the School Superintendent [who had been perceived as sympathetic to integration] was fired. His replacement was School Superintendent Dr. Kenneth McFarland. When he was hired as superintendent in 1942, McFarland stated that in Topeka, "separate schools are here to stay" (Kluger 1975:393). ${ }^{9}$ $\mathrm{McF}$ arland himself would later recall his segregation policy as merely maintaining the status quo in Topeka's schools: 10

we were operating the schools under essentially the same
structure that we took them over in $1942 . .$. We have no
objective evidence that there is any substantial desire for a
change among the people that the board represents... [T]here
is nothing in the record historically, that it's the place of
the public school system to dictate the social customs of the
people who support the public school system.

McFarland took over administration of Topeka's public schools right after the Grabam case. His policies reflected the re-alignment of the school board to continue the tightening of public segregation begun during Topeka's urban expansion and popu- 
lation growth in the 1920s and 1930s. McFarland held "back the tide" according to Topekan Samuel Jackson (Kluger 1975:404).

The ambivalence toward segregation in Topeka, however, can be illustrated by the willingness of the school board to negotiate and compromise. Jackson continues, " $[t]$ he school board might have gone along with desegregation...if McFarland had not resisted." The school board itself was divided on the issue of continuing segregation. Charles Scott's law partner, Charles Bledsoe wrote Robert Carter of the NAACP in New York that 11



When McFarland became adamant that school segregation continue in the primary grades, the school board suffered a re-alignment among its members toward segregation. As a result of this re-alignment, McFarland consolidated the power of its committees into his office; he could then override the elected authority of the elected school board. 12

McFarland's “iron hand" policy included hiring Harrison Caldwell as Director of Negro School Education to administer the segregated schools. ${ }^{13}$ Caldwell played on the existing fears of African American teachers by reminding them that they would all lose their jobs if the schools were integrated (Kluger 1975:381382). 14 Caldwell conducted yearly performance reviews of the teachers that included weighing their teaching in the classroom against their attitude toward the administration (Kluger 1975:381). Mamie Williams, who taught at Buchanan School and later was Principal at Washington School, recalled that her fellow teachers did not protest this practice for fear of losing their jobs: 15
Since nobody had tenure then and most of the teachers were unmarried women dependent on their salaries for their livelihood, you went along. (Kluger 1975:381)

Divisions in the African American community toward integration were also created through school organizations, such as the Negro Parent Teachers Association (PTA). According to Speer (1968:27) and Adler (1972:253 fn 103), the African American teachers in turn put pressure on Topeka's Negro PTA to further oppose challenges to segregation by influencing the parents of the children they taught. This resulted in African Americans acting in support of a white supremacist segregationist policy in order to preserve community and economic stability. McKinley Burnett stated
that the Negro PTA ...[had] sent a letter to the Board of Education expressing their official support of the Board position. Public...[segregated] school teachers hesitated even to comment on the case as it was being prepared for court (emphasis in original) (Speer 1968:27).

The local NAACP tried to overcome the teachers' reluctance and win their support for school integration. NAACP President, McKinley Burnett stated:16

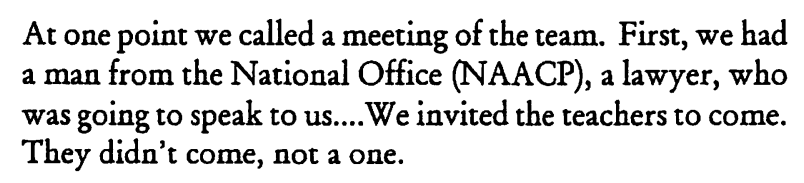

A second challenge to Topeka's Board of Education was an effort by white elites to remove Superintendent McFarland. Though this challenge did not overtly emphasize desegregation, it did challenge the same target: McFarland and members of the school board who supported him. The white elites' challenge and the African Americans' challenge were separate but complementary actions that were clearly not under any common organizational control. These separate challenges did not share organizational resources or leadership - as suggested by the local 
movement center model (Morris 1987). The school desegregation campaign was assisted indirectly, without overt participation by the white community. This assistance was through a separate but complementary challenge that targeted McFarland and his policies other than segregation.

Whites in Topeka began to challenge the way in which the school board and Superintendent McFarland's leadership of Topeka's schools by the late 1940s. ${ }^{17} \mathrm{McF}$ arland gave opponents plenty of ammunition, and the campaign against his regime articulated several grievances besides segregation. One of the primary criticisms of McFarland was his management style, which was autocratic. Frank Wilson, Principal of Sumner Elementary School, stated that "you were either a supporter of McFarland and considered yourself a 'company man' or you were out."18

McFarland's autocratic style of management and the manner in which he led the school board culminated in a challenge by white elites to both school board members and McFarland. While the Brown brief was being prepared for court in April of 1951, half of the school board responsible for hiring McFarland in 1942 was up for re-election (Wilson 1994:25). 19 On April 3, 1951 they were voted out of office. ${ }^{20} \mathrm{~A}$ few days after the election, on April 5, 1951, Superintendent Kenneth McFarland, turned in his resignation effective August, 1951.21

The election of new school board members and the resignation of School Superintendent Kenneth McFarland changed the commitment of the board of education to segregation. In September 1953 , two and a half months before the State of Kansas was to reappear before the United States Supreme Court in defense of its permissive segregation statute, the Board of Education of Topeka, Kansas, voted to abolish segregation in its elementary schools. 22

\section{Conclusion}

The indirect action tactics that resulted in school desegregation in Topeka were located within various types of organizations, including the civil rights oriented NAACP as well as community based types such as the AVC and even the PTA. This contrasts with Morris' (1984) local movement center model's emphasis on action located in the black churches and the religious domain. While African-American churches, long-standing mainstays of their communities, mobilized crucial resources in the Southern mass-mobilization campaigns. Necessary funds, other resources, and participants who could be mobilized were deployed by the formal and informal organizations, formal leadership, and communication networks concentrated in African American churches (Morris 1984:279).

The indirect action in Topeka was characterized by the combined efforts of formal and informal leaders as well as civil rights organizations such as the local chapter of the NAACP. There was not a concentrated location of collective action within the religious domain, even though the lead plaintiff, Oliver Brown, was studying for the clergy and worked part-time in St. John's A.M.E. church.23 Action was mounted by political and social justice organizations, civil rights attorneys, religious organizations, a veterans organization, and career activists working outside of established organizations. The eventual desegregation of Topeka's schools developed out of actions and tactics that began challenging segregation in public accommodations. These challenges were initiated by individuals addressing singular grievances and were joined by others who were affiliated with the NAACP and the community based AVC. Challenges to segregated schools was carried out once again by the NAACP, but included the ad hoc Citizens Committee, as well as individual efforts of Charles and John Scott, and their law partner, Charles Bledsoe. School desegregation was furthered by challenges by white elites to the McFarland administration and school board through its PTA, 
and responses by the black PTA and teachers. Diverse actions, separately controlled, loosely combined into what became the 1954 Brown case.

\section{Notes}

1. General Statute 21-2424, 1935.

2. General Statute 21-2424, 1935. Kansas City Call, September 26, 1947, and, November 24, 1947.

3. Kansas City Call, October 17, 1947.

4. Kansas City Call, October 17, 1947.

5. Kansas City Call, October 10, 1947.

6. Among those individuals who belonged to both organizations were two recently returned veterans named Charles and John Scott. The Scott brothers were both sons of local civil rights attorney Elisha Scott and would later argue the Brown case in Kansas Federal District Court Charles S. Scott Papers, Kansas Collection.

7. Stovall v. City of Topeka, 166 Kan. 35 (1948).

8. "...meetings of the Topeka NAACP were generally not attended by more than a dozen members" (Speer 1968:22). "The NAACP meetings that Burnett chaired rarely drew more than a dozen or so people and usually degenerated into gripe sessions" (Kluger 1975:393). The Citizens Committee did not present itself as an NAACP delegation, since "mention of the NAACP, it was presumed, would have earned the back of the school board's hand" (Kluger 1975:393).

9. McFarland denied his or the school board's involvement in expanding an informal system of segregation in Topeka High School See Brown v. Board of Education, 98 F Supp. 797 (1951); Transcript of Record in Lower Court, pp. 235-236. Burnett later described the race situation in the high school as : "Up there at the high school while they called it integrated, it was integrated only from the outside. When you got inside, it was just as Jim Crow as Alabama." See McKinley Burnett interview with Dr. Hugh Speer, April 1967, reported in Speer (1968) p. 22.

10. Brown v. Board of Education, 98 F Supp. 797 (1951); Transcript of Record in lower court, p. 234.

11. Correspondence from Charles Bledsoe to Robert Carter, Topeka NAACP Branch Files. Kansas State Historical Society, Topeka, Kansas.

12. All departments and divisions of the school system were unified under the superintendent, who alone was responsible to the Board for the execution of its policies (Kluger 1975:380).
13. Caldwell had worked under McFarland in Coffeyville, Kansas (Kluger 1975:381). For a personal account of Caldwell, see Merrill Ross' oral history transcript, Brown v. Board Oral History Collection. Ross was a coach and teacher under Caldwell during the 1940s.

14. Caldwell was described by the Citizen's Committee as "stumbling block to our progress and had...reduced the morale of the colored teachers 'to an all time low'” (Kluger 1975:393).

15. During the Grabam case, Mamie Williams taught sixth and seventh grade at the Buchanan School. See Brief for the Defendants, Grabam v. Board of Education of Topeka (19). During the time of the Brown case, Miss Williams was Principal at Washington School.

16. McKinley Burnett interview with Dr. Hugh Speer, April 1967. (Speer 1968:27).

17. Author interview with former Randolph School principal, Stan Stalter, July 17, 1994. Topeka, Kansas. Mr. Stalter recalled that faculty at Washburn University who had children in Topeka's public schools were particularly opposed to Superintendent McFarland's policies. Stalter felt that the "movement" to remove McFarland began in the schools around Washburn University.

18. Author interview, October 1994. Frank Wilson was Principal of Sumner Elementary when Oliver Brown tried enroll his daughter Linda, in 1950.

19. Author interview with Stan Stalter, July 17, 1994. Topeka, Kansas.

20. Two years later, on April 7, 1953, the remaining half of the members of the Board of Education were voted out of office. All who had been on the Board when the Brown lawsuit was filed were off the board by August 1953. The Brown case went to the United States Supreme Court on December 7, 1952. Memorandum on Brown compiled by the University of Kansas Law Library, Reference Desk, August 1995. Copy in the private collection of the author.

21. Topeka Capital, April 4, 1951; April 5, 1951.

22. There was only one negative vote, by Mr. Oberhelman, who stated that "he was no (sic) opposed to the policy, but felt that an orderly program should be worked out before the resolution was passed." Segregation Policy. Topeka Board of Education. Charles S. Scott papers. Kansas Collection. University of Kansas.

23. In the nineteenth century, the Social Gospel Movement was oriented toward the social domain of religion. The religious activism of Reverend Charles Sheldon resulted in social reforms for African Americans. 


\section{Bibliography}

Abramowitz, Jack. 1950. "Accommodation and Militancy in Negro Life 1876-1916." Ph.D. diss. Columbia University, New York.

Adler, Frank J. 1972. Roots in a Moving Stream. Kansas City, MO: Spangler Printing.

Bloom, Jack M. 1987. Class, Race E the Civil Rights Movement. Bloomington, II: Indiana University Press.

Blumberg, Rhoda Lois. 1984. Civil Rights: The 1960s Freedom Struggle. Boston, MA: GK Hall \& Company.

Blumer, Herbert. 1948. "Public Opinion and Public Opinion Polling." American Sociological Review, 13 (October): 542554

Branch, Taylor. 1988. Parting the Waters: America in the King Years, 1954-1963. New York, NY: Simon and Schuster.

Chafe, William H. 1980. Civilites and Civil Rights. New York, NY: Oxford University Press.

Cox, Thomas C. 1982. Blacks in Topeka, Kansas, 1865-1915. Baton Rouge, LA: Louisiana State University Press.

Dalfiume, Richard M. 1968. "The 'Forgotten Years' of the Negro Revolution." The Journal of American History. LV:90-106.

Freeman, Jo. ed. 1983. Social Movements of the Sixties and Seventies. New York, NY: Longman.

Garrow, David J. 1986. Bearing the Cross. New York,NY:Vintage.

Greenberg, Jack. 1994. Crusaders in the Courts: How a Dedicated Band of Laweryers Fought for a Civil Rights Revolution. New York, NY: Basic Books.

Killian, Lewis M. 1984. "Organization, Rationality and Spontaneity in the Civil Rights Movement." American Sociological Review. 49:770-783.

Killian, Lewis M. and Charles U. Smith. 1960. "Negro Protest Leaders in a Southern Community." Social Forces. 38:253257.
Klarman, Michael J. 1994. "How Brown Changed Race Relations: The Backlash Thesis." Journal of American History. June 81: 81-118.

Kluger, Richard. 1975. Simple Justice. New York, NY: Knopf.

Lawson, Steven F. 1991. "Freedom Then, Freedom Now: The Historiography of the Civil Rights Movement." American Historical Review. 96:456-471.

McAdam, Doug. 1982. Political Process and the Development of Black Insurgency, 1930-1970. Chicago, Il: University of Chicago Press.

Morris, Aldon D. 1984. The Origins of the Civil Rights Movement: Black Communities Organizing for Change. New York, NY: The Free Press.

Speer, Hugh W. The Case of The Century: A Historical and Social Perspective on Brown v. Board of Education of Topeka with Present and Future Implications. Project No. 6-8939. Contract No. OEC-3-7-068939-2841. Office of Education, U.S. Department of Health, Educationa and Welfare. May, 1968.

Turner Ralph and Lewis Killian. 1987. Collective Bebavior. Third Edition. Englewood Cliffs, NJ: Prentice-Hall.

Wilson, Paul E. 1995. A Time to Lose: Representing Kansas in Brown v. Board of Education. Lawrence, KS: University of Kansas. 